\title{
Pleural Mesothelioma cM1 TNM Finding v7
}

National Cancer Institute

\section{Source}

National Cancer Institute. Pleural Mesothelioma CM1 TNM Finding v7. NCI Thesaurus.

Code C88917.

Pleural mesothelioma with distant metastasis. (from AJCC 7th Ed.) 